\title{
FROM MUSAYLIMA TO THE KHĀRIJITE NAJDIYYA
}

\author{
Al Makin \\ State Islamic Univesity (UIN) Sunan Kalijaga, Yogyakarta, Indonesia
}

\section{Abstract}

This paper tries to reconstruct the following accounts: the defeat of Musaylima and the death of his prominent followers, and the rise of the Kharijite Najdiyya in Yamama. Moreover, this study seeks the evidence which points to the possible connection between Musaylima's movement and the Kharijite Najdiyya. This paper highlights that many founders and prominent leaders of the Kharijites, and particularly the Najdiyya sect, came from the tribe of Hanifa, to which Musaylima belonged. This, among other things, seems to have become the main impulse of attraction for the people of Hanifa to join the sect. Additionally, the 'characteristics' and the 'image' of the Najdiyya reflect those of Musaylima. This leads us to conjecture that the people of Hanifa, having failed to defend their prophet Musaylima and the land of Yamama against the Medinan caliphate under Abü Bakr in the Battle of 'Aqraba, later joined the Kharijite Najdiyya.

[Artikel ini menjelaskan kekealahan Musaylima dan kematian pengikutpengikut utamanya serta kemunculan aliran Khawärij Najdiyya di Yamāma. Melalui artikel ini, penulis membuktikan relasi antara gerakan Musaylima dan Khawärij Najdiyya. Ini bisa dibuktikan dengan mencermati fakta bahwa sebagian pendiri dan tokoh utama Khawärij, utamanya sekte Najdiyya, berasal dari suku Hanifa --suku yang juga menjadi asal muasal Musaylima. Kesamaan suku inilah --dan beberapa fak.tor lainnya-- nampaknya menjadi daya tarik tersendiri bagi orang-orang suku Hanifa untuk bergabung dengan sekte Najdiyya. Selain itu, 'Karakteristik' dan 'imej' sekte Najdiyya yang 
menyerupai gerakan Musaylima adalah hal lain yang turut menguatkan asumsi tersebut. Pandangan inilah yang kemudian mengantarkan penulis pada kesimpulan bahwa, setelah gagal mempertahankan nabi mereka, Musaylima, dan wilayah mereka, Yamāma, melawan khilafah Islam di Madinah yang dipimpin Abü Bakr, suku Hanifa memilib memberontak dan bergabung dengan sekte Khawärij Najdiyya.]

Keywords: Musaylima, Khārijite, Najdiyya

DOI: 10.14421/ajis.2013.511.33-60

\section{A. Introduction: the Defeat of a 'Prophet'}

In the last two years of the Prophet Muhammad's life, the Muslim community in Medina developed rapidly. At the same time, another prophet in Yamāma, named Musaylima, consolidated his political power. ${ }^{1}$ The conquest of Mecca was a turning point for the early Muslim community. After this event, many Arab tribes, as reported by sira (biography) and tärikh (historiography) literature, sent deputations to Medina to pay allegiance to the Prophet. ${ }^{2}$ In Yamāma, Hawdhā b. 'A $\sqrt{1}$, an influential political leader whose sway expanded from Central to North

${ }^{1}$ Although Musaylima was a prophet contemporary to Muhammad, only a few have seriously paid sufficient attention to this figure. Besides entries in the EI1 (Encyclopaedia of Islam, Brill, first edition), EI2 (Encyclopaedia of Islam, Brill, second edition), and EQ (Encyclopaedia of the Qur'an, Brill), the following articles have dealt with Musaylima: Dale F. Eickelman, "Musaylima, An Approach to the Social Anthropology of Seventh Century Arabia" JESHO Journal of Economy and Social History of the Orient) 10 (1967); M. J. Kister, "The Struggle against Musaylima and the conquest of Yamāma" JS AI (Jerusalem Studies in Arabic and Islam) 27 (2002). See also a review on Kister's work by Sellheim, "Zu M. J. Kister's Struggle against Musaylima” in Die Welt des Orients 35 (2005): pp. 158-68.

2 Some Muslim scholars have taken these classical reports at face value, see, for instance, Hamidullah, Le Prophète de l'Islam (Paris: Librairie Philosophique J. Vrin, 1959) vol. 1, pp. 433-434. Western scholars, however, have cast doubt on the accounts of deputations of some Arab tribes and their conversion to Islam; see Elias Shoufani, Al-Riddah and the Muslim Conquest of Arabia (Toronto: University of Toronto Press, 1973), p. 12. n. 4; W. Watt, Muhammad at Medina (Oxford: Oxford University Press, 1956) 80; W. Arafat, "An Interpretation of the Different Accounts of the Visit Tamim Delegation to the Prophet in A. H. 9" BSOAS (Bulletin of School for African and Asian Studies) 17 (1955), p. 424. 
Arabia, ${ }^{3}$ died and Musaylima then appeared to control the politics of Yamāma. Thumāma b. 'Uthāl, ${ }^{4}$ on the other hand, stood as an opposition, with the support of Medina from both the Prophet Muhammad himself during his lifetime and Abū Bakr, the first caliph. However, Musaylima, who was supported by numerous followers consisting of settled and nomad tribes, was stronger than Thumāma, whose followers constituted only a splinter group of the settled people. ${ }^{5}$

Although Musaylima's political power came later after Hawdhäs death, his claim of prophethood, according to some early Muslim sources, occurred no later than the Prophet Muhammad's. ${ }^{6}$ Musaylima's religious

${ }^{3}$ For more on Hawdhā, see, for instance, al-Kalbī, Jambarat al-Nasab li Ibn alKalbī, Mạ̣mūd Firdaws al-'Ażim and Mạ̣mūd Fakhūrì (ed.) (Damascus: Dār al-Yaqda al-'Arabiyya) vol. 2, p. 262; 'Abdallah b. 'Abd al-'Aziz al-Bakri, Mu'jam ma Ista'jam min Asmà' al-Bilād wa al-Mawāidi, Musțafā al-Saqā (ed.) (Cairo: Matba'a Lajna al-Ta'lif wa al-Tarjama wa al-Nashr, 1368/1949) vol. 3, p. 1063; al-Halabi, Insān al-Uyün fi Sirät al-Amin al-Ma'mūn/Sirā al-Halabiyya (Cairo: Musțafāa al-Bābi al-Halabi wa Awladu, n.d.) vol. 3, p. 303; Ibn Hadidah al-Anșarì, al-Miṣbāh al-Mūdi, Sharāf al-Dỉn Aḥmad Mudir (ed.)(Hyderabad: Dā'irat al-Ma‘̄arif al-'Uthmāniyya, 1396/1977) vol. 2, p. 355; Ibn al-Qayyim al-Jawziyya, Zād al-Ma'ād fi Hady Khayr al-'Tbād, Muhammad al-Mas'ūdi (ed.) (Cairo: al-Matba'a al-Misriyya, 1347/1928) vol. 3, p. 63.

4 On Thumāma, see, for instance, Donner F. McGraw. "Mecca's Food Supplies and Muḥammad's Boycott," JESHO 20 (1977): pp. 249-266. See also Ibn Sa'd, Ṭabaqāt al-Kubrā (Beirut: Dār Sadir, 1960) vol 5, pp. 550-551; Ibn al-Athir, Usud al-Ghäba fi Ma'rifat al-Ṣahāba (n.p.; n.d.) vol.1, pp. 246-9; Ibn Hajar al-Asqalāni, al-Isāaba fi Tamyiz al-Ṣahāba, 'A Ti Muhammad al-Bajawi (ed.) (Beirut: Dār al-Jil, 1992) vol. 1, p. 203.

5 Shoufani, al-Riddah 84; Kister, "The Struggle" 11; al-Maqrizi, Imtā' al-Asmä, bi mā li Nabi min al-Aḥwāl wa al-Amwàl wa al-Hafada wa al-Matā', Muhammad 'Abd alHamid al-Numaysi (ed.) (Beirut: Dār al-Kutub al-'Ilmiyya, 1999) vol. 14, pp. 536-7.

${ }^{6}$ Marsden Jones (ed.), Kitāb al-Maghäzì al-Wagidì (London: Oxford University Press, 1966), p. 82; al-Tha'álibi, Thimār al-Qulüb fi al-Mudāf wa al-Mansūb, Muhammad Abū al-Fadl Ibrāhim (ed.) (Cairo: Dār Nahda, 1384/1965), p. 146; Abū al-Fida’ Isma‘il b. 'Ali, Kitāb al-Mukebtasar fi Akbbär al-Bashār, Ibrāhim Kāmil al-Zayn and Adì 'Ārif al-Zayn (ed.) (Beirut: Dār al-Fikr, 1375/1956) vol. 2, p. 65; Ibn Shihnah, Rawḍ al-Manāż̈ir fi Tlm al-Awāil wa al-Awäkhir, Muḥammad Muhannnā (ed.)(Beirut: Dār al-Kutub al-'Ilmiyya, 1417/1998), p. 101. However, Ibn Ishạaq, supported by Ibn Hishām and al-Ṭabārī, dates the prophethood of Musaylimah at the late life of the Prophet Muhammad. See Tarikh al-Rusul wa al-Mulūk, Muhammad Abū al-Fadl Ibrāhim (ed.) (Cairo: Dāral-Ma ārif, 1962) vol. 3, p. 147; trans. Poonawala, History, pp. 107-8. See also Diyarbakri, Tärikh al-Khämis fi A ḥwäl Anfās Näfis (Beirut: Mu'assasa Sha'bān, n.d.) vol. 2, p. 158; al-Balansī, Tärỉkh al-Ridda, Iqtabāsa min al-Iktifä' li al-Kaläi al-Balansi, Khurshid Aḥmad Farìq (ed.) (New Delhi: Asia Publishing House, 1970), p. 58; al-Zurqani, Sharḅ 'ala al-Mawāhib al-Ladūniyya 
activities, as kabin (soothsayer) and Nabi (prophet) or rasul (messenger), began when he was in Haddār, ${ }^{7}$ the village where he was born. However, he gained no significant number of followers. ${ }^{8}$ When he moved to Hajar, the capital of Yamāma, the number of his followers increased considerably. After Hawdhä's death, Musaylima, perhaps inspired by the success of the Prophet Muhammad in Medina, seized the opportunity to combine both politics and prophetic mission as a means to achieve his goal of founding an independent Yamāma. He achieved considerable success, but only for two years. It was Khālid b. Walid's force --dispatched by Abū Bakr after the failure of 'Ikrima b. Abi Jahl's force in facing Musaylima's troops'-- which finally defeated Musaylima. Wahshi, a black slave who had killed Hamza, the Prophet Muhammad's uncle, claimed to have killed Musaylima in the fierce Battle of 'Aqraba. ${ }^{10}$

li al-Allama al-Qastallāni (Cairo: al-Azhar, 1327H) vol. 4, p. 20; al-Ya'qübī, Tärỉkh alYáqübi (Najaf: al-Haydariyya, 1384/1964) vol. 2, p. 120. See also some discussions on this, e.g. Margoliouth, "On the Origin and Import of the name Muslim and Hanif," JRAS (Journal of Royal Asiatic Society) 35 (1903), p. 485; C. J. Lyall, "The words hanif and Muslim," JRAS 35 (1903), pp. 771-84; F. Buhl, "Musailima," EI1; Watt, Muhammad at Medina (Oxford: Oxford University Press, 1968), p. 135; Eickelman, "Musaylima”, p. 33; Kister "The Struggle against Musaylima," pp. 4-6.

7 Kister, "The Struggle"; Ibn Manzur, "Haddār" in Lisān al-'Arab; Ibn al-Athir, Nihāya fi Gharib al-Hadith wa al-Athar, Abū 'Abd al-Raḥman Ṣalāh b. Muḥammad b. 'Uwayda (ed.) (Beirut: Dār al-Kutub al-'Ilmiyya, 1418/1998) vol. 5, p. 217. Haddār was a valley in the district of al-Falaj. See Abdullah al-Askar, al-Yamama in the Early Islamic Era (Reading: Ithaca, 2002), p. 15. It is also reported that Musaylimah owned a farm in this valley. Cf. Yaqūt, Mu'jam Irshād al-Arìb ila Ma'rifat al-Adib/Mu'jam al-Udabä', D.S. Margoliouth (ed.)(Cairo: Matba'ah Hindiyya, 1913) vol. 4, 258 and vol. 5, p. 258.

8 Al-Tha ālibi, Thimār al-Qulūb, p. 146; al-Waqidi, Kitāb al-Ridda, Riwaya Aḥmad b. Muhammad b. A'tham al-Kufi (d. 314), Yahya al-Juburi (ed.) (Beirut: Dār al-Gharb al-Istāmi, 1990/1410), p. 109.

9 Al-Ṭabāî, Tärikh vol. 3, 292; trans. Donner, History, p. 122.

${ }^{10}$ Kitāb al-Maghāzì al-Waqidì vol. 1, 286; al-Waqidi, Kitāb al-Ridda, p. 137; Tärikeh Khalifa b. Khayyād, Akram Diyā' al-'Umārī (ed.) (Najaf: Matba'ah al-Adab fi al-Najf alAshraf, 1386/1967), pp. 75-76; Al-Ya'qūbi, Tärikh vol. 2, p. 109; Al-Ṭabāri, Tärikeh vol. 3, p. 289. Al-Balādhū ri, on the other hand, mentions six killers: Khidash b. Bashir b. al-'Asim, 'Abdalla b. Zayd b. Tha'laba, Abū Dujana Simak b. Kharasha, 'Abdalla b. Zayd b. 'Asim, Wahshi, and Mu'áwiya b. Abỉ Sufyan. See al-Balādhūrī, Kitāb Futụ̣̄ al-Buldān, Șalāh al-Din al-Munajjid (ed.)(Cairo: Maktabat al-Nahda al-Misriyya, n.d.) v. 1, pp. 106-7; Ibn Hubaysh, Ghazwat Ibn Hubaysh/Kitāb al-Ghazawät al-Damina al-Kamila wa al-Futūh al-Jami'a al-Hafila al-Kä'ina fi Ayyām al-Khulafä' al-Awwäl al-Thalätha: Abi Bakr al-Siddiq wa Abï Hafs 'Umar wa Abi' 'Amr dhi al-Nurayn 'Uthmān, Suhayl Zakkar (ed.) (Beirut: Dār 


\section{B. The Followers}

This section presents the story of Musaylima's followers briefly, which Muslim sources still preserve. Ibn Sa'd, for instance, reports only the members of the deputation of the tribe of Hanifa who came to Medina and who are said to have converted to Islam. ${ }^{11}$ Yet Ibn Sa'd fails to mention the identities of Musaylima's supporters. So do later authors of many genres of Muslim literature, ranging from tabaqät (biographies), Sirā (biography of the Prophet), tärikh (historiography), Hadith (prophetic tradition), ijā̄ (miracle of the Qur'ann), tafsir (exegesis of the Qur'an), to rijal al-Hadith (transmitters of the tradition).

Most of al-Ṭabārìs stories of the Battle of Yamāma, for instance, focus on the accounts of Muslim troops under the command of Khâlid b. al-Walid. Various reports mention a number of names of Muslim commanders and warriors, whereas only a few names of those who fought on the side of Musaylima are mentioned. Al-Ṭabāri reports that the number of the Hanifa who fought on the side of Musaylima was forty thousand, ${ }^{12}$ although it is difficult to accept the reliability of this estimation. However, it would appear that Musaylima was supported by a huge number of followers from various tribes in Yamāma in the Battle of 'Aqraba and that the people of Hanifa were his main supporters. Most of the people of Tamim, a neighbour and competitor to the Hanifa, seemed to support their own prophetess, Sajah. ${ }^{13}$

According to the reports on the battle between the Hanifa and the Medinans, not only were the followers of Musaylima numerous, but they were also well organized, a fact which explains why to the extent that the Hanifa defeated Muslim troops under 'Tkrima b. Abi Jahl. ${ }^{14}$ In the al-Fikr, 1412/1992) vol. 1, pp. 87-8.

${ }^{11}$ Ibn Sa'd, Tabaqāt al-Kubrā vol. 1, p. 316. Wilhelm Hoenerbach also provides a list of those who stood against Musaylima during the Yamāma war; see his Watima's Kitäb ar-Ridda aus Ibn Hagar's Isäba, Ein Beitrag zur Geschichte des Abfalls der Araberstämme nach Muhammads Tod (Wiesbaden: Akademie der Wissensschaften und der Literatur, 1951), pp. 53-65.

${ }_{12}$ Al-Ṭabārí, Tärikh vol. 3, p. 281. Al-Balansì and Ibn Hubaysh preserved a testament by Khâlid b. al-Walid on the huge number of the tribe Hanifa; see Ibn Hubaysh, Ghazwat Ibn Hubaysh vol. 1 79; al-Balansi, Tärikh al-Ridda, p. 91.

${ }_{13}$ V. Vacca, "Sadjah" in EI2; al-'Asqalānī, Ișäba vol. 7, 723; Ṭabārî,Tärik bol. 3, pp. 272-4; J. Wellhausen, Skizzen und Vorarbeiten (Berlin: Walter de Gruyter, 1985) 12-15.

${ }^{14}$ Al-Ṭabāri, Tärikh vol. 3, p. 281. 
later battle under Khālid's command, a significant number of Muslims, ranging from the Medinans (Ansar), the Meccans (Mubajiruin) to the Bedouins, fell as martyrs (shubada $\bar{a}) .{ }^{15}$ From the story of the battle, we can only draw three names of Musaylima's prominent supporters, while the rest of them remain unidentified.

First, al-Rajjāl/al-Raḥhạal/al-Nahhār b. 'Unfuwa ${ }^{16}$ played a critical role in both propagating Musaylima's prophethood among the Hanifa and acting as a commander of his troops in the Battle of 'Aqraba. According to some akbbarr (reports) found in various genres of Muslim literature, al-Rajjāl came to Medina as a deputation member of the tribe of Hanifa, joining the Companions' circle where he learned the Qur'an and the Sunna ${ }^{17}$ under the instruction of a known Qur'anic reader, Ubayy b. Ka'b. Al-Rajjāl also made acquaintance with a prominent Hadith narrator, Abū Hurayra.

According to Muslim literature, al-Rajjāl called upon the people of Hanifa to testify to Musaylima's prophethood. ${ }^{18}$ Having stayed in Medina for a considerable period of time, he was familiar with the Muslim community and Islamic teachings. Upon his return to Yamāma, he informed Musaylima about the successful development of both Islam and the Muslim community. Al-Ṭabāri preserves a long report narrating how Musaylima consulted al-Rajjâl about many vital issues, including how to perform miracles and to imitate the way Muhammad had done so. ${ }^{19}$ From the Muslim perspective, however, Musaylima always failed to imitate

15 As many as 600 Muhajirun and Ansar were killed, whereas 7,000 of Hanifa were killed in 'Aqraba and another 7,000 in the garden of death (badiqat al-mawt). See al-Ṭabāri, Târikh vol. 3, 296. Muslim writers also mention some names of the martyrs; see, for instance, Tärikeh Khalifah b. Khayyāt, pp. 77-9; al-Balādhūrì, Kitäb Futūh al-Buldān vol. 1, pp. 109-11; Ibn Hubaysh, Ghazwat Ibn Hubaysh vol. 1, pp. 100-103; al-Dhahabi, al-Tbār fi Khabar man Ghabar, Șalāh al-Din al-Munajjid (ed.) (Kuwait: Mudir Ma'had alMakhtūtāt bi Jami’'a al-Duwāl al-'Arabiyya, 1960) vol. 1, pp. 14-5; Ibn al-Athir, al-Kämil fi al-Tärikk (Beirut: Dār Sadir, 1965) vol. 2, pp. 366-7; Ibn Kathir, al-Bidāya wa al-Nihāya (Beirut: Maktaba al-Ma`arif, 1966) vol. 6, pp. 334-41.

${ }^{16}$ Ibn Sa'd, Tabaqāt vol. 1, p. 316; J. Wellhausen, Medina vor dem Islam (Berlin: Walter de Gruyter, 1985), pp. 156-8; al-Tha ālibi, Thimār al-Qulüb, p. 147; Ibn Kathir, al-Bidāa vol. 6, p. 323.

17 Ibn Kathir, Bidāya vol. 6, 323; al-Ṭabāri, Tärikh vol. 3, pp. 284-285; trans. Donner, History, p. 117; al-Balansi, Tärikeh, p. 58; al-Maqrizìi, Imtā'al-Asma vol. 14, p. 230.

18 Al-Ṭabāri, Tärikh vol. 3, p. 282; History trans. Donner, p. 107.

19 Ibid. 
Muhammad. In the end, al-Rajjāl was killed in the Battle of 'Aqraba.

Second, Muhkam b. Țufayl or Muhkam al-Yamāma ${ }^{20}$ was also an important supporter of Musaylima, and worked as his wazir (adviser). ${ }^{21}$ In spite of the fact that Muslim reports say little about him, al-Waqidi cites a poem denouncing his support of Musaylima's prophethood. ${ }^{22}$

Third, Mujjā'ah b. Murāra adopted a rather ambiguous position between Musaylima's faction and the Medinans. On the one hand, it is said that after witnessing one of Musaylima's miracles, he testified to his prophethood. ${ }^{23}$ On the other hand, during the Battle, Mujja' $a$ ah and his followers were not on the battlefield with their prophet Musaylima. While seeking for the blood revenge from the tribe of 'Āmir, they were captured by Khâlid b. Walid's troop on the way to 'Aqraba. The troop kept Mujja' $a$ ah as a hostage and executed his followers. ${ }^{24}$ After the Battle of Yamāma, he mediated between the two warring factions and made them sign a treaty. ${ }^{25}$ Moreover, his daughter married Khālid and he himself led a deputation to Medina to acknowledge Abū Bakr's sovereignty over Yamāma. ${ }^{26}$

Apart from this information, the identity of most of Musaylima's followers remains enigmatic. The Muslim sources report that, having been defeated, some of the Hanifa were executed. Others are said to have converted to Islam. A number of them were also driven out of Yamāma. ${ }^{27}$

Tarikh literature portrays the Muslim troops as achieving total victory in the Battle of 'Aqraba and states that the followers of Musaylima who survived after the Battle surrendered to the Medinan authority. However, this story seems to contain a certain degree of simplification.

20 Al-Waqiidi, Kitāb al-Ridda, pp. 108-9; see also Aḥmad b. A'tham al-Kufi, alFutūh (Beirut: Dār al-Kitāb al-'Ilmiyya, 1406/1989) vol. 1, pp. 26-7.

21 Al-Waqidi, Kitāb al-Ridda, p. 113.

22 Ibid., p. 110.

23 Al-Jāḥiz, Kitāb al-Hayawān, 'Abd al-Salām Muhammad Hārūn (ed.) (Beirut: Dār al-Fikr, 1408/1988) vol. 4, p. 372.

${ }^{24}$ Al-Waqidi, Kitāb al-Ridda, pp. 120-121; Tärikh Khalifa b. Khayyāt, pp. 72-3; al-Ṭabārī, Tärikh vol. 3, p. 287.

${ }_{25}$ Al-Waqiedi, Kitāb al-Ridda, pp. 138; Tärikh Khalifa b. Khayyāt, pp. 76; al-Balādhūrì, Futüh vol. 1, pp. 108-109; al-Ṭabäri, Tärikeh vol. 3, pp. 297-8; Al-Balansi, Tärikeh al-Ridda, pp. 107-108; Hubaysh, Ghazwat Ibn Hubaysh vol. 1, pp. 91-2.

${ }^{26}$ Al-Waqidi, Kitāb al-Ridda, p. 146; al-Balansi, Tärikh al-Ridda, pp. 115-20.

27 Abdullah al-Askar, al-Yamāma, p. 35. 
There is no compelling evidence suggesting that all people of Yamāma surrendered to the Medinan authority upon their defeat. Nor is the story convincing when it states that the survivors among Musaylima's followers all converted to Islam.

On the contrary, I would like to argue that a certain number of Hanifa continued practicing Musaylima's cult. According to Hadith reports preserved in the collections of Hakim, Abū Dāwūd, and Ibn Kathir, the followers of Musaylima still practiced the rites of his cult during the time of 'Uthmān b. 'Affān, the third caliph. The way in which they did so is portrayed differently in the sources. One Hadith says that they only testified to Musaylima's prophethood in a mosque. ${ }^{28}$ Another states that they recited Musaylima's 'Qur'an' (scripture), which, according to another report, was called 'mushaf' (codex).$^{29}$ Ibn Kathir even cites the verses which they recited. ${ }^{30}$ 'Abdalla b. Mas'ud, according to these sources, ordered the execution of the leader of the cult, 'Abdalla b. Nawwāha, and drove the rest of the followers of Musaylima out of Yamāma.

The story of Musaylima's followers practicing the ritual cult in a mosque of Yamāma implies that after the Battle of 'Aqraba, Musaylima's followers continued to practice his cult, especially reciting their own qur'an or performing certain rites. Moreover, more than a century later, Ibn Ishạa consulted a Sheikh of Hanifa on the story of the deputation of the Hanifa to Medina. ${ }^{31}$ Two centuries later, al-Jăhiz met the people of Hanifa in Bașra, whom he consulted about Musaylima's revelations. ${ }^{32}$ Surprisingly, later Muslim sources preserve a number of stanzas attributed to Musaylima. ${ }^{33}$

28 Al-Dārimi, Sunan al-Dārimì (Damascus: Bāb al-Barìd, 1349 H) vol. 2, p. 235.

${ }^{29}$ Hakim Nisaburi, al-Mustadrak 'ala al-Sabihayn fi al-Ahādith (Riyad: Maktaba wa Matābi‘ al-Nasr li al-Hadith, n.d.) vol. 4, pp. 53-4.

${ }^{30}$ Ibn Kathir, al-Bidaya 5, pp. 51-2.

${ }^{31}$ Ibn Hishām, al-Sirā al-Nabawiyya, Musțafā al-Saqā, Ibrāhim al-Abyārī and 'Abd al-Hāfiz Shalbì (ed.)(Cairo: Shirka wa Matba'a al-Bābi Musțafā al-Halabì wa Awladu, 1375/1955) vol. 2, p. 576.

32 Al-Jāhiz, Hayawān vol. 4, p. 89.

33 See, for instance, one of stanzas attributed to Musaylima which bears similarities to surah al-A'la (Q. 87). Jawad ATi, al-Mufassal fi Tärikh al-Arab qabl al-Isläm (Beirut: Dār al-'Ilm al-Malāyin, 1970) vol. 8, p. 756; al-Tha'ālibi, Thimār al-Qulūb 147; Muțahar b. Țāhir al-Maqdisi, Kitāb al-Bad' wa al-Tärikh (Baghdād: al-Muthanna, 1916) vol. 5, pp. 161-162. 
The fact that Musaylima's cult was still practiced at the time of 'Uthmān leads us to speculate that this was also the case during the reigns of Abu Bakr and 'Umar. However, this only describes the loyal followers of Musaylima. This paper also seeks to explain that those who later converted to Islam joined the faction of 'Ali. In the later period, as Abdullah al-Askar argues, the people of Musaylima-who failed to obtain the independence of Yamāma from the Medinan authoritylater supported the Khärijite Najdiyya movement in their hometown. According to al-Askar, the sentiment of regionalism played a vital role in triggering both religious movements of Musaylima and the Najdiyya. ${ }^{34}$ In this regard, I try to present more clues to the connection between the two.

\section{The First Clue to the Link between Musaylima and the Najdiyya: Tribal Origin}

The following discussion presents the first clue conveying a possible link between the Khärijite movement and Musaylima's movement. That is, I draw attention to the tribal origins of the early Khärijite's leaders, particularly those of the Najdiyya sect.

According to modern scholars, the origin of the Khārijite movement remains puzzling ${ }^{35}$ regarding when and how it emerged. Traditional Muslim sources tell us that this political movement can be traced back to the arbitration (mubakkima) that took place in attempt to cease the conflict between the warring factions of 'A $\mathrm{Cl}$ and $\mathrm{Mu}^{\text {'a }}$ aiya. However, the Khärijites (or the Khawarij, those who seceded from the faction of 'ATi due to their disappointment with the arbitration) called upon the early Muslims to return to the law of God (la ạukma illà lilläh). ${ }^{36}$ In the theological realm, the Khärijites went further, condemning many early Muslim leaders, including 'Uthmān, 'ATi, Mu'âwiya and the rest of the Umayyad caliphs. This sect, however, did acknowledge the leadership

34 See Abdullah al-Askar, al-Yamāma, pp. 68-74.

35 See, for instance, Patricia Crone, God's Rule, Government and Islam (New York: Columbia University Press, 2004), p. 54. See also n. 58 below.

36 The above formula, according to Hawting, was "a summary of the scripturalist position and a protest against the Oral Law rather than a reaction to the arbitration agreement made at Șiffin." See his "The Significance of the Slogan "là hukkma illā lillāb" and the References to the "hudūd" in the Traditions about the Fitna and the Murder of 'Uthmān” BSOAS 41 (1978), p. 461. 
of Abū Bakr and 'Umar.

In terms of tribal origins, Watt points out that most of the Khärijites came from northern tribes. ${ }^{37}$ Madelung also remarks the same pattern that some northern tribes, under the umbrella of the Rabi'a, including the tribes Hanifa and the Tamim, supported 'Ali's faction during the War of Siffin. ${ }^{38}$ However, in the aftermath of the arbitration, these tribes joined the Kharrijites. This tribal affiliation is a point of departure for the way in which the Khärijite movement relate to Musaylima's movement.

From traditional Muslim accounts, one can conclude that tribal sentiment played a vital role in the leadership of the early Muslim community. During the election of Abū Bakr, for example, the Quraysh, a section of the Mudar, enjoyed the privilege in both politics and theology. Their nobility was justified by numerous traditions attributed to the Prophet Muhammad, ${ }^{39}$ who was himself a Qurayshite. The four rightly guided caliphs, many prominent Companions, the Umayyads, and the early Abbasid rulers also belonged to the Quraysh. This tribal sentiment also contributed to the politics and tribal alliance of later Muslim community. It is therefore unsurprising that the Tamim and the Hanifa, sections of Rabi'ah, joined the Kharrijites in order to protest against the Mudar who dominated both factions of 'AГi and Mu'āwiya.

Nonetheless, via their tribal affiliation to the Hanifa and the Tamim, we uncover the likely link between Musaylima's people and the Khārijites. This can be seen in the origins of some Kharrijite leaders. It is true that the early leaders of the Kharijites in terms of their tribal origins, as Wellhausen remarks, were heterogeneous. ${ }^{40}$ However, the Tamim and

37 Montgomery Watt, Islamic Philosophy and Theology, An Extended Survey (Edinburgh: Edinburgh University Press, 1985), p. 5. See Watt, Islam and the Integration of Society (London: Routledge, 1961) eg. pp. 94-103; and Watt, The Formative Period of Islamic Thought (Edinburgh: Edinburgh University Press, 1973) eg. pp. 10-11.

38 W. Madelung, The Succession to Muhammad, A Study of the Early Caliphate (Cambridge: Cambridge University Press, 1997), pp. 229 and 232; Madelung, "Rabi'a in the Jahiliyya and in Early Islam" JS AI 28 (2003), pp. 155-157, 162, 164, and 232.

39 See, for instance, Aḥmad b. Hanbal, Musnad (Beirut: Dār Sadir, n.d.) vol. 3, pp. 129, 193 and vol. 4, p. 421.

${ }^{40}$ The following figures were Tamimites: Mis'ar b. Fadaki (Ṭabāri, Tärỉkh vol. 5, p. 76), Hurqus b. Zuhayr (Ṭabāri, Tärikh vol. 5, p. 75; Dinawāri, Akbbār, p. 204), 'Urwa b. Udayya, and Abū Bilal (Mirdas b. Udayya, d. 61/680-1) (Ṭabāiri, Tärikh vol. 5, p. 55; Mubarrad, Kāmil vol. 3, pp. 1098, 1185-86; Levi Della Vida, EI2; S. Sears, 
the Hanifa later dominated the leadership of this sect.

To begin with, 'Urwa b. Udayya al-Hanzali was the leader of the Tamim who protested the arbitration between 'Ali's faction and Mu'awiya's. Due to this, a clash occurred between the Tamim and the Yemenite tribes under Ash'ath b. Qays, ${ }^{41}$ the chief of Kinda of Küfa, who accepted the condition proposed by $\mathrm{Mu}^{\prime}$ a'wiya. It is said that 'Urwa cried that 'the arbitration belongs only to God. ${ }^{42}$

The founder and leader of the section Azāriqa of Khārijites, Nāfic b. Azrāq (d. 65/685) was indentified both as Tamimite and Hanafite. ${ }^{43}$ 'Abidah b. Hilal, an important supporter of the Azāriqa, belonged to the Yashkur tribe, many of whose members lived in Yamāma. ${ }^{44}$ The following

"Umayyad Partisans or Khārijite Rebel?: The Issue of Abd al-Ażiz b. MDWL” Studia Iranica 21 (2002), p. 74; Ibn Abi al-Hadid, Sharh Nabj al-Balägha, Hasan Tamim (ed.) (Beirut: Dār Maktaba al-Hayya, 1963, vol. 2), p. 7. For the Tamimite members of the Khārijites who were mostly Qur'ān readers (qurra'), see al-Ash'ārì, al-Ibāna 'an usul aldiyana (the Elucidation of Islam's Foundation), trans. Walter C. Klein (New York: Kraus Reprint, 1967), p. 7. According to Shaban, however, the word reads qurra, instead of qurra', see n. 58 below.

The following figures were Mudarites: Farwa b. Nawfal al-Ashja i (Ṭabāri, Tärikh vol. 5, p. 86. Dinawāri, al-Akbbār al-Ṭiwāl, 'Abd al-Mun'im 'Āmir and Jamāl al-Dìn al-Shayyāl (ed.) (Cairo: Wizārat al-Thaqāfa wa-al-Irshād al-Qawmī, al-Iqlīm al-Janūbī ; al-Idāra al-'Āmma lil-Thaqāfa, 1960) , p. 210; Shuraỵ̣ b. Abỉ Awfa al-Ibsì (Ṭabārì, Tärikeh vol. 5, p. 75. Dinawäri, al-Akhbār, p. 202), 'Abdalla b. Shajara al-Sulāmì (Ṭabāri, Tärikh vol. 5, p. 83), and Hamza b. Sinan al-Asadi (Ṭabäri, Tärikh vol. 5, pp. 74-5).

The following figures were Ṭayyi: Zayd b. Husain (Ṭabāri, Tärikh vol. 5, p. 85. Dinawā̄ì, al-Akbbār, p. 203), Mu'adh b. Juwayn, and Ṭarafa b. 'Adi b. Hatim (Ṭabāri, Tärikh vol. 5, p. 75; Dinawāri, al-Akbbār, p. 205).

The following figures were Yemenites: Yazid b. Qays al-Arhabi, 'Abdalla b.

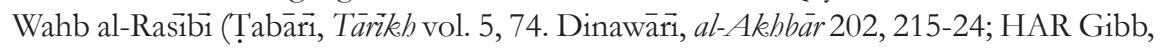
EI2; Madelung, The Succession to Muhammad 250-52, p. 258), and Ibn Muljam al-Murādi, the Murder of 'Ali (al-Mubarrad, al-Kāmil, Muhammad Aḥmad al-Dāli (ed.) (Beirut: Mu'assasat al-Risāla, 1406/1989) vol. 3, pp. 1115-1121. See also Julius Wellhausen, The Religio-Political Factors in Early Islam, trans. R.C. Ostle and S.M. Walzer (Oxford: NorthHolland Publishing Company, 1975), p. 16, e.g. n. 9.

${ }^{41}$ Dinawāri, al-Akbbār, p. 211.

${ }^{42}$ Montgomery Watt, Islamic Philosophy and Theology, p. 5; Islam and the Integration of Society, pp. 94-103; The Formative Period, pp. 10-11.

${ }^{43}$ Wellhausen, The Religio-Political Factors, pp. 45, 50, n. 3; Ṭabäri, Tärikh vol. 2, p. 517.

${ }^{44}$ Wellhausen, The Religio-Political Factors, p. 51. n. 3. Hawdhā b. 'Ali was also a Yashkurite. For the sources of his pedigree, see n. 4 above. 
Khārijites --'Abdalla b. Ṣaffār, 'Abdalla b. 'Ibād, Hazala b. Bayhas, 'Abdalla, 'Ubaydalla, and Zubayr-- came from the Tamim. ${ }^{45}$

The most successful movement of the Kharrijites in terms of political endeavours was the Najdiyya faction led by Najda b. 'A mir alHanafi, ${ }^{46}$ which had separated from Nāfi b. Azrāq's section, ${ }^{47}$ and whose main supporters --Abū Țâlūt Salim b. Matar, Abū Fudayk 'Abdalla b. Thawr, ${ }^{48}$ and 'Atiyya b. al-Aswad ${ }^{49}$-- came from the Hanifa. Another important leader of the early Khārijites, Hassan b. Bahdaj, was also a Hanafite. $^{50}$

Early Khārijites concentrated in Küfa, where they survived into the Abassid era. Basta then also became a base of this sect, where the Najdiyya split from the Azarriqa in the second civil strife. ${ }^{51}$ From Baṣra the Azāriqa went eastward, reaching Iran. ${ }^{52}$ The Najdiyya, having moved to and ruled Yamāma, conquered many surrounding areas, including Bahrain, Oman, parts of Yemen, and Hadramawt in the south and south-west. ${ }^{53}$

As a leader of the Khärijites, Najda, whom they called amir almu'minin (the commander of the faithful), ${ }^{54}$ was of course hostile to the

45 Ibid., p. 45.

46 Al-Mubarrad, al-Kämil vol. 3, pp. 1102, 1104, for his consultation to Ibn 'Abbas on religious matters see, for instance, vol. 3, p. 1121.

${ }^{47}$ R. Rubinacci, EI2.

${ }^{48}$ K. Lewinstein, EI3 (third edition). Shahrastāni, Kitāb al-Milal wa al-Nihal, Muhammad b. Fath Allah Badran (ed.)(Cairo: Matba'at al-Azhar, 1328/1990), p. 215; al-Baghdāđi, al-Farq bayn al-Firaq, Muhammad Muhy al-Din 'Abd al-Hamìd (ed.) (Cairo: Maktaba Muhammad 'AГi Subayh, n.d.), p. 88. See also M.Th. Houtsma, EI2; Tabäri Tarikh vol. 2, p. 829.

49 Wellhasuen, The Religio-Political Factors, p. 45.

${ }^{50}$ Ibid., p. 51.

51 Shahrastāni, Kitāb, p. 217; Keith Lewinstein, "Making and Unmaking a Sect: The Heresiographers and the Șufriyya," SI 76 (1992), p. 96; Patricia Crone, God's Rule 55; Crone, "A Statemetn by Najdiyya", p. 56.

52 Crone, God's Rule, p. 55.

${ }^{53}$ Ibn Abi al-Hadid, Sharh Nabj vol. 3, p. 8. Watt estimates that Najda's sway extended over larger areas than 'Abdalla b. Zubayr's. See Watt, The Formative Period, p. 23; Watt, Islamic Philosophy, p. 9. Whereas Najda conquered Bahrain, Yemen and Hadramawt, 'Ațiyya b. al-Aswad marched on Oman. But soon the latter quarrelled with the former and founded the 'Atawiyya section. See Rubinacci, EI2.

${ }^{54}$ Shahrastāni, Kitāb al-Milal, p. 212. 
Umayyads, the original nemesis of 'Ali's faction. It was not surprising that he supported Zubayrid faction, which, however, he finally left. This moment was also marked by the fact that he and his men moved from Baṣra to Yamāma. This sect was known for its instability. It is not surprising that these Khārijite leaders --Najda, Abū Ṭâlūt, Abū Fudayk, and 'Atiyya-- were also involved in the serious quarrels over religious and political matters. Najda was finally killed by his own companion, Abū Fudayk. ${ }^{55}$

Thus, the fact that the founder of the Najdiyya, Najda b. 'Āmir, and its main leaders --e.g. Abū Fudayk, Abū Ṭālūt, and Ibn al-Aswad-were Hanafites may have become the main impulse of attraction for the people of Haniffa. Abū Ṭălūt, whom Najda appointed as a governor of Yamāma, centered his activities in Khadhārim, where four thousand slaves of Hanifa were employed by the Umayyads to cultivate land. ${ }^{56}$ Thus, in a certain way, the emergence of the Khärijites in Yamāma served as a new hope for the people of Hanifa, a movement which might liberate them from the power of the Umayyads, whom they detested. In fact, Musaylima had previously failed to liberate them from the Medinan caliphate.

\section{The Second Clue: 'Characteristics' and 'Images'}

Early 'Kharijitism' was a movement of 'puritanism,' or at least a movement that emphasized religious piety. ${ }^{57}$ Some also argue that this

${ }_{55}$ Najda was accused of committing sins in the eyes of the Khärijites, e.g. his unacceptable independent judgement (ijtihä d), his protection of 'Uthmān's family, and his compromise with the caliph 'Abd al-Mālik b. Marwan. Additionally, Najda failed to build a stable relation with the tribe of Hanifa. When he moved his center to Bahrain, some of them withdrew their support. See, for instance, Abdullah al-Askar, al-Yamàma, pp. 68-74. Ref. cited.

${ }^{56}$ Ibn al-Athir, al-Kämil vol. 4, p. 201; cf. Micheal J. Morony, The History of alTabäri, p. 163. n. 486; J. Wellhausen, Religiös-politischen Oppositionensparteien im altern Islam (Berlin: Weidmansche Buchhandlung, 1901), p. 30.

${ }^{57}$ In this regard, J. Wellhausen argues that this sect, whose main teaching consisted of returning to the Qur'an and the Sunna, had strong roots in the teachings of Islam itself. See his The Religio-Political Factors, pp. 17-18. Elie Adib Salem also underlines the religious sentiment which triggered the birth of the Khärijites, rather than the political motivation; see his Political Theory and Institutions of the Khawarij (Baltimore: The Johns Hopkins Press, 1956). Micheal G. Morony subscribes to the same opinion, adding the positive side of the early Kharijites in maintaining the equal status among the Arab Muslims and respecting the non-Muslims; see his Iraq after the Muslim Conquest (Princeton: 
sect had a strong bond with the spirit of Arab tribalism. ${ }^{58}$ The two characteristics can also be found in the accounts of Musaylima. From certain stanzas attributed to him, we may draw the conclusion that this prophet also endorsed his followers to practice a certain form of piety and asceticism, e.g. restricting certain sexual activities, prohibiting wine drinking, intoxicated drinks or mixed drinks. ${ }^{59}$ However, many Muslim

Princeton University Press, 1984), pp. 468, and 470-71. See also, Fred. M. Donner, “Piety and Eschatology in Early Khärïite Poetry" Fi Mihrab al-Ma 'rifa (Beirut: Dār Sader Publishers, 1997). Watt argues that, having envisioned an ideal pious community, the Khārijites represented a form of 'charismatic society' in the early history of Muslim community. See his "The Conception of the Charismatic Community in Islam" Numen 7 (January, 1960), pp. 77-90; Watt, "Conditions of Membership of the Islamic Community," SI (Studia Islamica) 21 (1964), p. 7.

However, Shaban proposes that social factors and economical interests which likely triggered the emergence of this movement. That is, a particular group of Muslim community called qurra (lit. villagers/Bedouins), who were entrusted in the early Muslim community as an army to conquer new lands, blamed 'Uthmān for injustices he committed, and then seceded from 'Ali's faction due to economical and social dissatisfaction. This group was likely the proto-Khārijites. See M. A. Shaban, Islamic History, A.D. 600-750 (A.H. 132): A New Interpretation (Cambridge: Cambridge University Press, 1971), pp. 50-76. See also the meaning of qurra' as Qur'an readers in n. 35 below. For more discussion on some views of modern Muslim and Western scholars on the Khärijites, see for instance, Hussam S. Timani who reviews each of these views in his Modern Intellectual Readings of the Khärïites (Berlin: Peter Lang, 2008).

58 R.E Brünnow, Die Charidschiten unter den ersten Omayyaden (Leiden: n.p., 1884), e.g. 8 and elsewhere. Crone highlights the 'libertinism' of the Khärijite in terms of character (see her God's Rule 63), whereas Watt their 'egalitarianism' (see his The Formative Period, pp. 24-25).

59 On the restriction of sexual intercourse and the prohibition of wine drinking in one of Musaylima's stanzas, see, al-Ṭabāri, Tärỉkh vol. 3, p. 272; mod. trans. Donner, History 93-4. (Qultu lahum là al-nisa' ta'tun/I said to them, You shall not come to women. Wala al-khamr tashrabun/Nor drink wine). On the prohibition of consuming mixed or adulterated drink, see al-Ṭabāri, Tärikh vol. 3, p. 284; mod. trans. Donner, History, p. 109; al-Baqillanī, I'jāz al-Qur'ān, Sayyid Aḥmad Saqr (ed.) (Cairo: Dār al-Ma'ārif, n.d.), p. 239; al-Harūni, Ithbät Nubuwwat al-Nabì, KhaFil Ahmad Ibrāhim al-Hajj (ed.)(Cairo: Dār al-Turāth al-'Arabi, 1399/1979), p. 38. (Waqad ḅurrima al-madhq, famā lakum là tumajja' inn/Adulterating milk has been forbidden; so what you have, do not consume date mixed with milk).

The spirit of puritanism can also be seen in certain proponents of the hanif, such as Abū Ämir who accused the Prophet Muhammad of mixing his version with extra-haninif elements. See Ibn Sa'd, Ṭabaqāt al-Kubrā vol. 2, p. 321; al-'Asqalāni, Ișāba vol. 1, p. 250; Ibn Kathir, al-Bidāya vol. 2, p. 221. 
scholars convey a 'negative' image of Musaylimah, according to which he allowed his people drink wine and commit adultery. ${ }^{60}$ Musaylima also performed certain forms of prayers and fasting. ${ }^{61}$ However, Muslim authors accuse him of reducing the number of prayers originally ordered by the Prophet Muhammad. ${ }^{62} \mathrm{He}$ also taught his people loyalty to tribal alliance, and due to this he praised the Tamim for their tribal loyalty. ${ }^{63}$

As in the case of Musaylima, the image of the Najdiyya is also related to wine and adultery. That is, Najda is reported to have tolerated wine drinking, or at least did not order the execution of big sinners, e.g. thieves, wine drinkers and adulterers (whom he regards as ghayr mushrikin/non-polytheists). ${ }^{64}$ The main teachings of the Najdiyya, as reported by later sources, was knowing God and His Messengers. ${ }^{65}$ Interestingly, the two main teachings can also be found in the accounts of Musaylima. In one of his stanzas, Musaylima explains the attributes of

${ }^{60}$ Ibn Hishām, Sirah v. 2, p. 576; al-Ṭabāri, Tärikh v. 3, pp. 137-8; Ibn 'Abd al-Barr, al-Durar fi Ikhtisār al-Maghäżi wa Siyār, Shawqi Ḍayf (ed.) (Cairo: Dār al-Taḥ̂̄ir, 1966), p. 270; al-Halabi, Insān al- 'Uyūn vol. 3, p. 155; Al-Ṣaliḥi al-Shāmi, Subul al-Hudā wa al-Rashād fi Sirā khayr al-Tbād, Ibrāhim al-Tarži and 'Abd al-Karim al-'Uzbawì (ed.) (Cairo: Wizāra Awkāf, Lajna Iḥyā al-Turāth al-Islāmi, 1402/1982) vol. 6, p. 497.

${ }^{61}$ Musaylima also used 'the call for prayer.' See al-Ṭabāiri, Târikh vol. 3, pp. 283-4. See also Musaylima's stanza, which reads "Fa abyakum 'alayna min salawat ma'shar $a b r a \bar{r} /$ For us some prayers of the company of the pious, ... Yaqumun al-layl wa yasumun al-nahar/Staying up at night and fasting by day." See al-Ṭabāri, Tärikh vol. 3, p. 272; mod. trans. Donner, History, p. 93; al-Nuwayri, Nibāyat al-Arab vol. 19, p. 78.

${ }^{62}$ Al-Ṭabāri, Tärikh vol. 3, p. 274.

${ }^{63}$ See one of Musaylima's stanzas preserved by al-Ṭabāri, Tärikh v. 3, pp. 283-4; trans. Donner, The History, p. 109. (Inna bani Tamimin qawm tabr laqāḥ/ The tribe Tamim is a people of purity and [quite] responsible. La makruba 'alaybim wa là ițāwä/Nothing can force them and nothing can influence them. Nujawirubum ma hayyina bi ihsān/Let us form allies with them (the Tamim) to stand. Numni'uhum min kulli Insān/Let us protect every person of them).

${ }^{64}$ See Shahrastāni, Kitāb al-Milal, p. 214; al-Baghdādi, al-Farq, p. 89; al-Ash`̄āri, al-Ibāna (The Elucidation), p. 7.

${ }^{65}$ See also for the rest of the teachings of Najdiyya, al-Baghdāid, al-Farq, p. 89; Shahrastāni, Kitāb al-Milal, p. 216; Ibn Abi al-Hadid, Sharḥ Nabj vol. 3, pp. 8, 10; Shahrastāni, Kitāb al-Milal, p. 216; Ibn Hazm, al-Faș fi al-Milal wa-al-Abwä’ wa al-Nị̣al, Muḥammad Ibrāhìm Naṣr, 'Abd al-Raḥmān 'Umayra (ed.) (Beirut: Dār al-Jīl,1405/1985) vol. 5, 53; vol. 4, p. 149. 


\section{Al Makin}

God and his great role in human life. ${ }^{66}$ Thus, the seeds of monotheism were present in Yamāma before the people there converted to Islam

${ }^{66}$ See al-Ṭabāri, Tärikh vol. 3, p. 272; mod. trans. Donner, History, p. 93; alNuwayri, Nihayat al-Arab, vol. 19, p. 78. (Sami'a Allah li man sama'God listened to whomever He listened to. Wa atma'uh bi al-khayri idh tama'/And made him yearn for good when he yearned. Wa lā zala amruh fi kull ma sarra nafsub yajtami'/And His cause is still arranged in everything that delights him. Ra'akum rabbukum fabayyakum/Your Lord saw you and gave you life. Wa min wahshat khallakum/And preserved you from loneliness. Wa yawm dini anjakum/And saved you and gave you life on the day of His religion). From this stanza, we can perhaps draw the attributes of God as follows: the Listener, the Generous one, the Arranger of detailed things, the Watcher, the life Giver, the salvation Giver, and the 'Friend' of man in loneliness. 
or joined the Najdiyya movement. So far, it is beyond our knowledge whether Musaylima knew the Biblical prophets, some of whose names are preserved in the Qur'ann. ${ }^{67}$ What is certain is that he himself claimed prophethood. ${ }^{68}$

Musaylima and the Khārijites shared the same fate, being depicted negatively in most of the sources by their adversaries. The stories of Musaylima and his followers have been preserved by his nemesis, the Muslim community. Similarly, the accounts of the Khärijites, which come down to us, were recorded by later Mu'tazilite and Sunnite authors. It is therefore not surprising that their narration often shows a hostile attitude to the subject. ${ }^{69}$ Unfortunately, we have no original record written by the followers of the two movements.

Musaylima's cult and the Kharijties also shared a common dislike of the Quraysh. Musaylima's proposal to Muhammad to divide the land of Arabia into two, half for the former and the other half for the latter,

${ }^{67}$ In one of his stanzas, Musaylima called God as al-Rahmān (the Merciful One), whose tone sounds Biblical; see al-Ṭabāri, Tärikh vol. 3, pp. 283-4. Musaylima himself was also known as Rahmān al-Yamäma; see al-Suhayli, al-Rawd al-Unuf fi Tafsir al-Sirā al-Nabawiyya li Ibn Hishām, Țāhā 'Abd al-Rawf Sa'd (ed.) (Cairo: Maktaba alKulliyat al-Azhariyya, n.d.) vol. 4, p. 225. For the discussion on the use of al-rabmann in the pre-Islamic period, see Nöldeke, Geschichte des Qorans, ed. F. Schwally (Hildesheim: Georg Olms, 1961) vol. 1, pp. 112-113, n. 3; A. Jeffery, The Foreign Vocabularies of the Qur'an (Baroda: Oriental Institute, 1938), pp. 140-141; Sprenger, Das Leben und die Lehre des Mohammeds nach Bischer Grösstentheils Unbenutzeten Quellen (Berlin: Nocolai'ische Verlagsbuchhandlung, 1861) vol. 2, pp. 198-210.

${ }^{68}$ See his declaration, Musaylima rasul allah (Musaylima, the messenger of God), in his letter to Muhammad, n. 71 below. Given this, one may also speculate that Musaylima realized the existence of some previous prophets serving as models for his claim of prophethood, as did Muhammad.

69 Patricia Crone, "A Statement by the Najdiyya Khärijites on the Dispensability of the Imamate," SI 88 (1998), p. 55; Keith Lewinstein, “The Azāriqa in Islamic Heresiography” BSOAS 54 (1991): p. 251. In this regard, Jeffrey T. Kenney argues that the Khärijites also served as a symbol employed by later Sunnite authors representing any form of extremism in Islam. See his "Heterodoxy and Culture: The Legacy of the Khārijites in Islamic History", Ph.D Dissertation, University of California, Santa Barbara, 1991, p. 78 and elsewhere. Additionally, later Sunnite authors attributed a tradition-that a 'black slave' acting as a leader of 'ummah' must be obeyed - to the Khärijites. However, Crone finds that this mere attribution has no convincing evidence. See her, "Even an Ethiopian Slave': The Transformation of a Sunnī Tradition,” BSOAS 57 (1994) 59-67. As such, later Sunnite authors played a certain role in shaping the image of the Khärijites. 
was rejected. In a letter to Muhammad, Musaylima also protested against the political domination of the Quraysh. He described the tribe as qawm ya'tadūn (the people who transgressed). ${ }^{70}$ The Kharrijites continued to rebel against the Umayyads, who were part of the Quraysh. Similarly, the Umayyads also showed hatred towards the Hanifa. Caliph 'Abd al-Mālik b. Marwan claimed that it was $\mathrm{Mu}^{\prime}$ awwiya, the founder of the Umayyad dynasty, who killed Musaylima. ${ }^{71}$ Likewise, the Hanifa also transmitted a tradition, according to which the Prophet said 'wayl banu umayya/woe to the faction of Umayyads. ${ }^{72}$ The Umayyads, in turn, oppressed the Hanifa, making them as slaves to cultivate their lands (as mentioned above).

We can further relate Musaylima's movement to Najdiyya. It is reported that, having been defeated in Yamāma and Bahrain, the remaining followers of Najda escaped to Bașra. ${ }^{73}$ It seems not to be a sheer coincidence that al-Jāhiz once came to Bașra to consult the people there about the revelation of Musaylima (as indicated earlier). Thus, connecting the two events leads us to speculate that the Hanifa, who had joined the Khärijites, still preserved Musaylima's story when they settled in Bașra.

We can perhaps reconstruct the chronological narrative of the people of Hanifa from the defeat of Musaylima to the rise of Najdiyya as follows. Although certain leaders of the Hanifa, e.g. Mujjā'ah b. Murāara, paid allegiance to the Medinans' sovereignty, not all of Musaylima's followers entirely abandoned his cult. They still practiced it down to the time of 'Uthmān, as indicated earlier. Later, the people of Hanifa

${ }^{70}$ On the various sources of the letter, see Muhammad Hamidullah, Majmu' $a$.

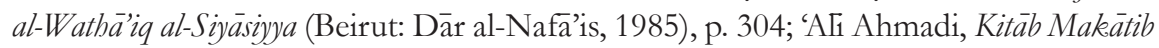
al-Rasul (n.p.: n.d.) vol. 1, p. 167; Ibn Hishām, al-Sirā al-Nabawiyya vol. 2, p. 600. Most of Muslim scholars accepted the redaction of Ibn Hishām, e.g. al-Bayhaqi, al-Mahăàsin wa al-Masāwi, Muhammad Kāmil Afandi al-Na'sāni (ed.) (Cairo: al-Sa'ādah, 1325/1906) vol. 1, pp. 22-23; Al-Dhahabi, Tärỉkh al-Islām wa Wafāyat al-Mashābir wa al-A lām, 'Umar 'Abd al-Salām Tadmūrì (ed.) (Beirut: Dār al-Kitāb al-Arabi, 1410/1990) book al-Maghā̄ìi, p. 686. Al-Balādhūri, however, gives a different redaction; see Al-Balādhūrì, Kitāb Futūh al-Buldān vol. 1, p. 106.

${ }^{71}$ Ibn Sa‘d, Ṭabaqāt al-Kubrā vol. 1, p. 316; Wilhelm Hoenerbach Watima’s Kitāh, pp. 53-65.

${ }^{72}$ Ibn al-Athir, Usud al-Ghāba fi Ma rifa al-Ṣahăba (n.p.: n.d) vol. 2, pp. 342-343; Al-'Asqalāni, Isāaba vol. 2, p. 70.

${ }^{73}$ al-Baghdādi, al-Farq, p. 90. 
who converted to Islam joined 'AFi's faction in the Șiffin war to integrate themselves in the Muslim community. Consequently, $\mathrm{Mu}^{\text {'a }}$ awiya and most of the Umayyads became their enemies. In addition, the alliance of the Hanifa with 'Ali's faction was also supported by the fact that 'Ali married a women from the tribe of Hanifa, Khawla bt. Ja ${ }^{6} \mathrm{far},{ }^{74}$ who was captured during the Yamāma war. Khawla gave birth to Muhammad b. Hanāfiyya, ${ }^{75}$ whom the Shi'ite faction led by Mukhtār b. Abi 'Ubayd's later venerated. Thus, the presence of Khawlah and his son on the side of 'A 5 may have also played a role in attracting the people of Hanifa to join this faction. In the aftermath of the mubakkima-when the Khärijite materialized in the form of political movement led by the Tamim and the Hanifa figures_-some people of Hanifa joined this movement. When Yamāma became the center of the Najdiyya, more people of Hanifa must have joined this sect.

\section{E. Concluding Remarks}

Having presented the above picture, we can conclude with the following remarks. There is no name belonging to Musaylimah's movement which survived until the emergence of the Khärijites. Nor was there any name which belonged to both Musaylimah's movement and the sect Najdiyya. The numerous followers of Musaylima, including al-Rajjāl b. 'Unfuwwa and Muhkam b. Ṭufayl, were killed together with their prophet in the war of Yamāma. The last followers of Musaylima who still practiced his cult were led by Ibn Nawwāha at the time of 'Uthmān. The leader was executed, and his followers were driven out of Yamāma. The Khārijite movement emerged later at the time of 'AГr. The sect Najdiyya materialized at the later civil strife between the Marwanids and the Zubayrids. Given these facts, it is difficult to pinpoint the direct link between Musaylima's movement and the Khārijites.

However, in view of the fact that some leaders of the Khärijites, particularly the sect Najdiyya, came from the Hanifa, we may hypothesize that this gave impetus to the people of Hanifa to join the movement.

${ }^{74}$ Ibn Abi al-Hadid, Sharb Nabj vol. 1, p. 201.

${ }^{75}$ For more on Muhammad b. Hanāfiyya, see, for instance, F. Buhl, in EI2; 'Abd al-Ameer 'Abd Dixon, Umayyad Caliphate 65-86/684-705 (A Political Study) (London: Luzac, 1971), p. 40; S. Husain M. Jafri, Origins and Early Development of Shi' Islam (London: Longman, 1979), pp. 228-29, 235-37, 239-42. 
Particularly, the activities of the sect Najdiyya were centered in Yamāma, the town of Musaylima. This further strengthens al-Askar's finding that both Musaylima and the Khärijite Najdiyya shared the same regional sentiment against the political domination of the Prophet and later caliphs. It is also true that the Kharijites employed this sentiment against the Quraysh, represented by both factions of 'AFi and Mu'a awiya in the aftermath of the mubakkima. In the later Muslim politics, the Quraysh were represented by the Umayyads, against whom the Khārijites continued to rebel. ${ }^{76}$ Thus, Musaylima and the Kharijtes have been perceived as nothing but rebellious factions. The former was against the Prophet, whereas the latter against the caliphs. The image of the two was unsurprisingly blackened, e.g., the Najdiyya was depicted as allowing adultery and wine drinking, as was Musaylima.

It is also worth noting that Ibn Isḥāq and al-Jạhiz met the people of Hanifa who had preserved some accounts of Musaylima. Thus, the former followers of Musaylimah seem to have spread in many Muslim cities, including Bașra and Baghdād in the aftermath of the execution of their last leader, Ibn Nawwāha. Interestingly, Baṣra also became one of the centers of the Kharijites.

From reading Musaylima's stanzas, the link may be extended not only to Musaylima and the Khārijite Najdiyya, but also to Musaylima and Islam itself. The similarities between Musaylimah's teachings and early Islam are not surprising, given the fact that the two were siblings, born in more or less the same place and time, i.e., the Arabian peninsula in the seventh century. Both prophets, Muhammad and Musaylima, delivered their revelations using the same style of $s a j^{6}$ (rhyme prose), ${ }^{77}$ and they

${ }^{76}$ For example, Abū Hamza al-Mukhtār b. 'Awf (d. 130/748) continued the rebellion against the Umayyads. See his speech which depicts the sinful acts of many caliphs of Umayyad, and which is still preserved by al-Azdi, Tärikh al-Mawsil (Dār alTahririr, 1967), p. 104; GAS 1, pp. 350, 104-105; Crone and Hinds, God's Caliph, p. 132. For more on Abū Hamza, see T. Lewicki, "Le Ibadites dans l'Arabie du sud au moyen age" Folia Orientalia 1 (1959); J. van Ess, "Das Kitāb al-Irja des Hasan b. Muhammad b. al-Hanāfiyya," Arabica 21 (1974), p. 41; Michael Cook, Early Muslim Dogma (Cambridge: Cambridge University Press, 1981), p. 166.

77 A few of stanzas attributed to Musaylima feature repetitive oaths, which are also commonly found in some early Meccan revelations of the Qur'an. See, for instance, al-Tabāri, Tärikh vol. 3, p. 283; trans. Donner, History, p. 108; al-Baqillani, I'jāz al-Qur'ān, pp. 238-9; al-Harūni, Ithbät Nubunwat, p. 38. See also the discussion on 
conveyed Qur'āns (readings), ${ }^{78}$ whose content, diction, and style bear substantial similarities. ${ }^{79}$ What is also clear is that the two figures served as prophets and tribal leaders who propagated monotheism. ${ }^{80}$ However, Islam survives until today, whereas Musaylima's cult disappeared a long time ago.

this, Nöldeke, Geschichte des Qorans vol. 1, pp. 75-76; D. V. Frolov, Classical Arabic Verse: History and Theory of 'Arud (Leiden: Brill, 2000), p. 119 and elsewhere.

${ }^{78} \mathrm{It}$ is worth recalling that the former followers of Musaylima read his Qur'an or mushaf. According to Richard Bell, the Qur'ann refers to broader readings, which may include any readings other than the Qur'an. References to the specific standard Qur'an must have occurred at the later period of Islam. See Richard Bell, A Commentary on the Qur'an, Edmund Bosworth and M.E.J. Richardson (ed.) (Manchester: Manchester University Press, 1991) vol. 2, p. 329.

${ }^{79}$ See fn. 34 above. Maxime Rodinson has already pointed out some basic similarities between Musaylima and Islam; see his Mohammed (New York: Penguin Books, 1971), p. 272.

80 See fn. 67 above. 
Al Makin

\section{BIBLIOGRAPHY}

'Ali, Abū al-Fida' Isma'il b., Kitāb al-Mukhtasar fi Akbbār al-Bashār, ed. Ibräbim Kāmil al-Zayn and Adỉb 'Ārif al-Zayn, vol. 2, Beirut: Dār alFikr, 1375/1956.

Ahmadi, 'AT, Kitāb Makātib al-Rasul, vol. 1, n.p.: n.d.

al-'Umārì, Akram Diyā' (ed.), Tärikh Khalifa b. Khayyād, Najaf: Matba'ah al-Adab fi al-Najf al-Ashraf, 1386/1967.

al-Anșarì, Ibn Hadidah, al-Missbāh al-Müdi, vol. 2, ed. Sharāf al-Din Ahmad Mudir, Hyderabad: Dā’irat al-Ma‘ārif al-'Uthmāniyya, 1396/1977.

al-Askar, Abdullah, al-Yamama in the Early Islamic Era, Ithaca: Reading, 2002.

al-Asqalānī, Ibn Hajar, al-Ișäba fi Tamyìr al-Ṣahăba, vol. 1, ed. 'A Ti Muhammad al-Bajawi, Beirut: Dār al-Jil, 1992.

al-Athir, Ibn, al-Kāmil fi al-Tärikh, vol. 2, Beirut: Dār Sadir, 1965.

----, Usud al-Ghāba fi Ma'rifa al-Ṣạ̧āba, vol. 2, n.p.: n.d.

al-Azdi, Târikh al-Mawsil, Dār al-Tahririr, 1967.

al-Baghdādi, al-Farq bayn al-Firāq, ed. Muhammad Muhy al-Din 'Abd alHamid, Cairo: Maktaba Muḥammad 'Ali Subayḥ, n.d.

al-Bakrî, 'Abdallah b. 'Abd al-'Ażiz, Mu'jam ma Ista'jam min Asmä' al-Biläd wa al-Mawàdi', vol. 3, ed. Musțafã al-Saqā, Cairo: Matba'a Lajna alTa'lif wa al-Tarjama wa al-Nashr, 1368/1949.

al-Balādhūrì, Kitāb Futūụ al-Buldān, vol. 1, ed. Șalāh al-Dīn al-Munajjid, Cairo: Maktabat al-Nahda al-Misriyya, n.d..

Al-Balansì, Tärikeh al-Ridda, Iqtabäsa min al-Iktifä' li al-Kaläi al-Balansì, ed. Khurshid Ahmad Fariq, New Delhi: Asia Publishing House, 1970. al-Baqillani, I'jā̄ al-Qur'ān, ed. Sayyid Aḥmad Saqr, Cairo: Dār al-Ma‘àrif, n.d.

al-Barr, Ibn 'Abd, al-Durarfi Ikbtișär al-Maghäzi wa Siyär, ed. Shawqi Dayf, Cairo: Dār al-Taḥrìr, 1386/1966.

al-Bayhaqi, al-Maḥāin wa al-Masāwi, vol. 1, ed. Muhammad Kāmil Afandì al-Na'sāni, Cairo: al-Sa àdah, 1325/1906.

al-Dārimì, Sunan al-Dārimi, vol. 2, Damascus: Bāb al-Barìd, 1349 H. 
al-Dhahabi, al-Tbār fi Khabar man Ghabar, vol. 1, ed. Șalāh al-Din alMunajjid, Kuwait: Muđir Ma‘had al-Makhtūtāt bi Jami‘'a al-Duwāl al-'Arabiyya, 1960.

----, Tärikeh Al-Islām Wa Wafāyat Al-Mashāhir Wa Al-A lām, ed. 'Umar 'Abd al-Salām Tadmūrì, Beirut: Dār al-Kitāb al-'Arabi, 1410/1990. al-Hadid, Ibn Abi, Sharḥ Nahj al-Balägha, vol. 2, ed. Hasan Tamim, Beirut: Dār Maktaba al-Hayya, 1963.

al-Halabì, Insān al- 'Uyün fi Sirät al-Amin al-Ma'mün/Sirāa al- Halabiyya, vol.

3, Cairo: Musțafã al-Bābi al-Halabì wa Awladu, n.d.

al-Harūni, Ithbät Nubuwwat al-Nabi, ed. Khalil Aḥmad Ibrāhim al-Haji, Cairo: Dār al-Turāth al-'Arabi, 1399/1979.

Ari, Jawad, al-Mufassal fi Tärikeh al-'Arab qabl al-Islām, vol. 8, Beirut: Dār al-'Ilm al-Malāyin, 1970.

Al-Jāhìiz, Kitāb al-Hayawān, vol., ed. 'Abd al-Salām Muhammad Hārūn, Beirut: Dār al-Fikr, 1408/1988.

al-Jawziyya, Ibn al-Qayyim, Zàd al-Ma'àd fi Hady Khayr al-Tbàd, vol. 3, ed. Muhammad al-Mas'ūdi, Cairo: al-Matba'a al-Misriyya, 1347/1928. al-Kalbi, Jambarat al-Nasab li Ibn al-Kalbi, vol. 2, ed. Maḥmūd Firdaws al'Ażim and Mạ̣mūd Fakhūrì, Damascus: Dār al-Yaqda al-'Arabiyya, nd.

al-Kufi, Ạ̣mad b. A'tham, al-Futūh, vol. 1, Beirut: Dār al-Kitāb al-'Tlmiyya, 1406/1989..

al-Maqdisi, Mutțahar b. Țāhir, Kitāb al-Bad' wa al-Tärikh, vol. 5, Baghdād: al-Muthanna, 1916.

al-Maqrizizi, Imtā' al-Asmā' bi ma li Nabi min al-Ahwàl wa al-Amwàl wa al-Hafada wa al-Matā', vol. 14, ed. Muhammad 'Abd al-Hamid alNumaysi, Beirut: Dār al-Kutub al-'Ilmiyya, 1999.

al-Mubarrad, al-Kāmil, vol. 3, ed. Muhammad Aḥmad al-Dāli, Beirut: Mu'assasat al-Risāla, 1406/1989.

al-Shāmì, Al-Ṣaliḥi, Subul al-Hudà wa al-Rashād fi Sirā khayr al-Tbād, vol. 6, ed. Ibrāhim al-Tarzì and 'Abd al-Karìm al-'Uzbawì, Cairo: Wizāra Awkāf, Lajna Iḥyā al-Turāth al-Islāmi, 1402/1982.

al-Suhayli, al-Rawd al-Unuf fi Tafsir al-Sirā al-Nabawiyya li Ibn Hishām, 
vol. 4, ed. Țāhā 'Abd al-Rawf Sa'd, Cairo: Maktaba al-Kulliyat alAzhariyya, n.d.

al-Tha'álibī, Thimār al-Qulüb fi al-Mudäf wa al-Mansūib, ed. Muhammad Abū al-Fadl Ibrāhim, Cairo: Dār Nahda, 1384/1965.

al-Waqièi, Kitāb al-Maghā̌ri, vol. 1, ed. Marsden Jones, London: Oxford University Press, 1966.

----, Kitāb al-Ridda, Riwaya Aḥmad b. Muḥammad b. A'tham al-Kufi (d. 314), ed. Yahya al-Juburi, Beirut: Dār al-Gharb al-Islāmi, 1990/1410. al-Ya'qūbi, Târikh al-Ya'qübi, vol. 2, Najaf: al-Haydariyya, 1384/1964.

al-Zurqani, Sharh 'ala al-Mawāhib al-Ladūniyya li al-'Allama al-Qastallāni, vol. 4, Cairo: al-Azhar, $1327 \mathrm{H}$.

Arafat, W., "An Interpretation of the Different Accounts of the Visit Tamim Delegation to the Prophet in A. H. 9", BSOAS Bulletin of School for African and Asian Studies) 17, 1955.

Bell, Richard, A Commentary on the Qur'an, vol. 2, ed. Edmund Bosworth and M.E.J. Richardson, Manchester: Manchester University Press, 1991.

Brünnow, R.E, Die Charidschiten unter den ersten Omayyaden, Leiden: n.p., 1884.

Buhl, F. , "Musailima," EI1, Leiden: Brill.

Cook, Michael, Early Muslim Dogma, Cambridge: Cambridge University Press, 1981.

Crone, Patricia, "A Statement by the Najdiyya Khārijites on the Dispensability of the Imamate," SI 88, 1998.

----, God's Rule, Government and Islam, New York: Columbia University Press, 2004.

Dinawārì, al-Akbbār al-Ṭiwāl, ed. 'Abd al-Mun'im ‘Āmir and Jamāl al-Dìn al-Shayyāl, Cairo: Wizārat al-Thaqāfa wa-al-Irshād al-Qawmī, alIqlīm al-Janūbī; al-Idāra al-'Āmma lil-Thaqāfa, 1960.

Dixon, 'Abd al-Ameer 'Abd, Umayyad Caliphate 65-86/684-705 (A Political Study), London: Luzac, 1971.

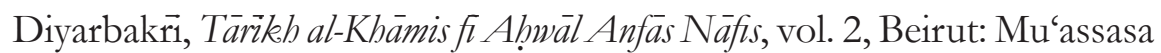
Sha'bān, n.d. 
Donner F. McGraw. "Mecca’s Food Supplies and Muhammad's Boycott," JESHO (Journal of Economy and Social History of the Orient) 20 (1977): 249-266.

----, "Piety and Eschatology in Early Khärïite Poetry" Fi Mibrab al-Ma'rifa, Beirut: Dār Sader Publishers, 1997.

Eickelman, Dale F., "Musaylima, An Approach to the Social Anthropology of Seventh Century Arabia" JEHSO (Journal of Economy and Social History of the Orient) 10, 1967.

Ess, J. van, "Das Kitāb al-Irja des Ḥasan b. Muḥammad b. al-Ḥanāfiyya," Arabica 21, 1974.

Frolov, D. V., Classical Arabic Verse: History and Theory of 'Arud, Leiden: Brill, 2000.

Hamidullah, Muhammad, Le Prophète de l'Islam, vol. 1, Paris: Librairie Philosophique J. Vrin, 1959.

----, Majmū'a al-Wathā'iq al-Siyāsiyya, Beirut: Dār al-Nafầis, 1985.

Hanbal, Aḥmad b., Musnad, vol. 3, Beirut: Dār Sadir, n.d.

Hazm, Ibn, al-Fasl fì al-Milal wa-al-Ahwà' wa al-Niḥal, vol. 5, eds. Ibrāhīm Naṣr, 'Abd al-Raḥmān 'Umayra, Beirut: Dār al-Jīl,1405/1985.

Hishām, Ibn, al-Sirā al-Nabawiyya, vol. 2, ed. Musțafā al-Saqā, Ibrāhim al-Abyārì and 'Abd al-Hāfiz Shalbì, Cairo: Shirka wa Matba'a al-Bābi Musțafã al-Halabī wa Awladu, 1375/1955.

Hoenerbach, Wilhelm, Watima's Kitāb ar-Ridda aus Ibn Hagar's Ișāba, Ein Beitrag zur Geschichte des Abfalls der Araberstämme nach Mubammads Tod, Wiesbaden: Akademie der Wissensschaften und der Literatur, 1951.

Hubaysh, Ibn, Gharwat Ibn Hubaysh / Kitäb al-Ghazawät al-Damina al-Kamila wa al-Futūh al-Jami' a al-Hafila al-Kä'ina fi Ayyàm al-Khulafä' al-Awwäl al-Thalatha: Abi Bakr al-Siddiq wa Abi Hafs 'Umar wa Abi 'Amr dbi al-Nurayn 'Uthmān, vol. 1, ed. Suhayl Zakkar, Beirut: Dār al-Fikr, 1412/1992.

Ibrāhim, Muhammad Abū al-Fadl (ed.), Tārikh al-Rusul wa al-Mulūk, vol. 3, Cairo: Dār al-Ma āarif, 1962.

Jafri, S. Husain M., Origins and Early Development of Shi'a Islam, London: Longman, 1979. 
Jeffery, A., The Foreign Vocabularies of the Qur'an, Baroda: Oriental Institute, 1938.

Kathir, Ibn, al-Bidāya wa al-Nibāya, vol. 6, Beirut: Maktaba al-Ma ārif, 1966.

Kenney, Jeffrey T., "Heterodoxy and Culture: The Legacy of the Khārijites in Islamic History", Ph.D Dissertation, University of California, Santa Barbara, 1991.

Kister, M.J. , "The Struggle against Musaylima and the conquest of Yamāma”, JS AI (Jerusalem Studies in Arabic and Islam) 27, 2002.

Levi Della Vida, EI2; S. Sears, "Umayyad Partisans or Khārijite Rebel?:

The Issue of Abd al-Aziz b. MDWL”, Studia Iranica 21, 2002.

Lewicki, T., "Le Ibadites dans l'Arabie du sud au moyen age", Folia Orientalia 1, 1959.

Lewinstein, Keith, "Making and Unmaking a Sect: The Heresiographers and the Șufriyya," SI 76, 1992.

Lewinstein, Keith, "The Azāriqa in Islamic Heresiography” BSOAS 54, 1991.

Lyall, C. J., "The words Hanif and Muslim," JRAS 35 (1903); 771-84.

Madelung, W., "Rabi'a in the Jahiliyya and in Early Islam" JS AI 28, 2003.

----, The Succession to Muhammad, A Study of the Early Caliphate, Cambridge: Cambridge University Press, 1997.

Manzur, Ibn, "Haddār" in Lisān al-Arab; Ibn al-Athìr, Nihàya fi Gharib al-Hadith wa al-Athar, vol. 5, ed. Abū 'Abd al-Raḥman Șalāh b. Muhammad b. 'Uwayda, Beirut: Dār al-Kutub al-'Ilmiyya, 1418/1998.

Margoliouth, "On the Origin and Import of the name Muslim and Hanif," JRAS (Journal of Royal Asiatic Society) 35, 1903.

Morony, Micheal G., Iraq after the Muslim Conquest, Princeton: Princeton University Press, 1984.

Nisaburi, Hakim, al-Mustadrak' 'ala al-Sabihayn fi al-Aḥadith, vol. 4, Riyad: Maktaba wa Matābi' al-Nasr li al-Hadith, n.d.

Nöldeke, Geschichte des Qorans, vol. 1, ed. F. Schwally, Hildesheim: Georg Olms, 1961.

Rodinson, Maxime, Mohammed, New York: Penguin Books, 1971.

Sa'd, Ibn, Ṭabaqāt al-Kubrā, vol. 5, Beirut: Dār Sadir, 1960. 
Salem, Elie Adib, Political Theory and Institutions of the Khawarij, Baltimore: The Johns Hopkins Press, 1956.

Sellheim, "Zu M. J. Kister's Struggle against Musaylima" in Die Welt des Orients 35, 2005.

Shaban, M.A., Islamic History, A.D. 600-750 (A.H. 132): A New Interpretation, Cambridge: Cambridge University Press, 1971..

Shahrastānī, Kitäb al-Milal wa al-Nihal, ed. Muhammad b. Fath Allah Badran, Cairo: Matba'at al-Azhar, 1328/1990.

Shihnah, Ibn, Rawd al-Manāzir fi 'Ilm al-Awà'il wa al-Awäkhir, ed. Muḥammad Muḥannā, Beirut: Dār al-Kutub al-'Ilmiyya, 1417/1998.

Shoufani, Elias, Al-Riddah and the Muslim Conquest of Arabia, Toronto: University of Toronto Press, 1973.

Sprenger, B., Das Leben und die Lehre des Mohammeds nach Bischer Grösstentheils Unbenutzeten Quellen, vol. 2, Berlin: Nocolai'ische Verlagsbuchhandlung, 1861.

Timan, Hussam S., Modern Intellectual Readings of the Khärïites, Berlin: Peter Lang, 2008.

Vacca, V., "Sadjah" in EI, Leiden: Brill.

Watt, "Conditions of Membership of the Islamic Community," SI (Studia Islamica) 21, 1964.

Watt, Montgomery, Islam and the Integration of Society, London: Routledge, 1961.

----, Islamic Philosopby and Theology, An Extended Survey, Edinburgh: Edinburgh University Press, 1985.

----, Muhammad at Medina, Oxford: Oxford University Press, 1956.

----, Muhammad at Medina, Oxford: Oxford University Press, 1968.

----, The Formative Period of Islamic Thought, Edinburgh: Edinburgh University Press, 1973.

Wellhausen, J., Medina vor dem Islam, Berlin: Walter de Gruyter, 1985.

----, Religiös-politischen Oppositionensparteien im altern Islam, Berlin: Weidmansche Buchhandlung, 1901.

----, Skizzen und Vorarbeiten, Berlin: Walter de Gruyter, 1985.

----, The Religio-Political Factors in Early Islam, trans. R.C. Ostle and S.M. 
Al Makin

Walzer, Oxford: North-Holland Publishing Company, 1975.

Yaqūt, Mu'jam Irshäd al-Arìb ila Ma'rifat al-Adïb/Mu'jam al-Udabä', vol. 4, ed. D.S. Margoliouth, Cairo: Matba'ah Hindiyya, 1913. 